Jurnal Agribisains ISSN 2550-1151 Volume 6 Nomor 2, oktober 2020

\title{
ANALISIS KELEMBAGAAN USAHATANI JERUK PAMELO DI KABUPATEN MAGETAN
}

\author{
W Nahraeni ${ }^{\mathrm{b}}$, A Rahayuc ${ }^{\mathrm{c}}$, S Masithoh ${ }^{\mathrm{b}}$ dan F Maharani $^{\mathrm{a}}$ \\ ${ }^{a}$ Mahasiswa Program Studi Agribisnis Fakultas Pertanian, Universitas Djuanda Bogor \\ b Staf Pengajar Progaram Studi Agribisnis Fakultas Pertanian, Universitas Djuanda Bogor \\ c Staf Pengajar Progaram Studi Agroteknologi Fakultas Pertanian, Universitas Djuanda \\ Bogor \\ J1. Tol Ciawi 1, Kotak Pos 35 Bogor 16720 \\ E-mail : wini.nahraeni@unida.ac.id
}

\begin{abstract}
ABSTRAK
Magetan mrupakan sentra produksi pamelo di Jawa Timur. Di Magetan, lemahnya posisi tawar petani Jeruk pamelo dicirikan dengan sistem pemasaran yang diijonkan ketika masih di kebun sehingga harga menjadi murah. Salah satu cara mengembangkan ushatani jeruk pamelo adalah melalui pemberdayaan kelembagaan petani. Penelitian ini bertujuan untuk menganalisis faktor penghambat, pendorong dan strategi penguatan kelembagaan untuk meningkatkan usahatani Jeruk Pamelo. Penelitian dilakukan di Kecamatan Sukomoro, Bendo, dan Takeran Kabupaten Magetan Provinsi Jawa Timur. Pengambilan sampel petani dilakukan dengan metode simple random sampling berjumlah 37 orang petani, dan pengurus kelompok tani berjumlah 21 orang yang diambil secara purposive. Data dianalisis secara deskriptif eksplanatori dan analisis medan kekuatan (Force Field Analysis). Hasil penelitian menunjukkan terdapat 18 faktor penghambat dan 12 faktor pendorong faktor penghambat terdiri atas umur petai tua, pendidikan, penerapan teknologi, pemeliharaan, kualitas bibit, sistem tebasan, penentuan harga, sumber pemasaran, akses pasar, manajemen gapoktan, peran serta petani, kualitas buah tidak menentukan harga, rendahnya kerjasama dalam pengadaan saprodi, kurangnya informasi dan akses ke lembaga keuangan, kemarau panjang, tingginya serangan hama dan penyakit, dan pandemi. Faktor pendorong terdiri atas pengalaman petani, keberagaman aksesi, kepemilikan lahan, kemudahan menjual hasil, petani aktif berkomunikasi, aktif mencari informasi budidaya, adanya pedoman teknik budidaya, bantuan bibit, bimbingan, penyuluhan, APM, kios sarana produksi, dan kesuainya materi PPL. Strategi penguatan kelembagaan adalah meningkatkan akses informasi dengan lembaga penunjang, membuat kerjasama penyampaian informasi, bimbingan dan evaluasi, menjaga kelestarian berbagai aksesi, bekerja sama dengan lembaga pemasaran/ asosiasi yang dapat meningkatkan bergaining position petani, akses dan informasi pemasaran.
\end{abstract}

Kata kunci: Strategi, SWOT, FFA, Kemebgaan petani 


\section{PENDAHULUAN}

\section{Latar Belakang}

Jeruk merupakan buah yang berperan penting karena mempunyai permintaan dan nilai ekonomis yang tinggi. Menurut Food and Agriculture Organization Indonesia merupakan negara ke-8 sebagai produsen jeruk dunia (FAO, 2018). Dari sisi konsumsi permintaan jeruk tahun 2016 sebesar $3,41 \mathrm{~kg} / \mathrm{kap} / \mathrm{tahun}$ atau sebesar 882.689 ton. Berdasarkan data BPS tahun 2018 produksi Jeruk Pamelo di Indonesia mengalami penurunan sebesar 21,31 persen atau setara dengan 27,734 ton dibanding tahun 2017 (BPS, 2019).

Jawa Timur merupakan provinsi dengan produksi ke dua tertinggi yang berkontribusi sebanyak 17,60 persen dari total produksi Jeruk Pamelo di Indonesia. Jeruk Pamelo merupakan buah unggulan Kabupaten Magetan yang dapat menghasilkan 7.727 ton per tahun atau 50,97 persen dari total produksi Jeruk Pamelo di Jawa Timur (Kementan, 2016). Tingginya permintaan yang belum diiring dengan peningkatan produksi membuat usahatani Jeruk Pamelo sangat berpotensi untuk dikembangkan.

Di Kabupaten Magetan, fakta di lapangan menunjukkan posisi tawar petani lemah sehingga harga sepenuhnya ditentukan oleh tengkulak, disebabkan petani terdesak masalah keuangan, waktu panen serentak dengan rentang waktu sempit. Kondisi ini diperparah oleh beberapa aksesi tidak memiliki masa simpan lama. Pemasaran pamelo di Magetan dilakukan dengan diborongkan dan dipanen pada waktu yang sama baik pada buah muda maupun buah tua, yang berakibat pada kualitas buah

Peraturan Menteri Pertanian Nomor: $\quad$ 82/Permentan/Ot.140/8/2013 dalam Pedoman Penumbuhan dan
Pengembangan Kelompok Tani dan Gabungan Kelompok Tani menyebutkan bahwa yang dimaksud kelembagaan petani adalah lembaga yang ditumbuhkembangkan dari, oleh, dan untuk petani untuk memperkuat dan memperjuangkan kepentingan petani. Kelembagaan petani terdiri atas kelompok tani, gapoktan, asosiasi petani dan dewan komoditas pertanian nasional yang berisikan dua aspek penting yaitu "aspek kelembagaan" dan "aspek keorganisasian" (Kementrian Pertanian 2013, 2016).

Selanjutnya dalam konteks penguatan kelembagaan, upaya untuk memperkuat posisi tawar petani adalah memperkuat kelembagaan melalui perubahan struktural terhadap kelembagaan lokal untuk meningkatkan taraf hidup petani, keterampilan maupun kapasitas kelembagaan

Hasil penelitian (Yuniarti, Susilo, Albayumi 2017) menunjukkan bahwa kelembagaan petani tebu berperan untuk membantu aktivitas petani dan meningkatkan posisi tawar petani dalam menjalankan agribisnis tebu. Namun kelembagaan petani umumnya banyak kepentingan kelompok tertentu dalam menjlankannya, sementara akses petani kecil terbatas baik ke lembaga finansial maupun non finansial.

Kelembagaan

usahatani memiliki potensi untuk meningkatkan produktivitas dan pendapatan serta kesejahteraan pelaku usahatani. Penguatan kelembagaan merupakan suatu kebutuhan yang penting dilakukan supaya petani dapat bersaing untuk meningkatkan kesejahterannya, karena pendapatan optimal hanya dapat dicapai dengan meningkatkan posisi tawar petani (Sumardjo 212). 


\section{Tujuan Penelitian}

Penelitian ini bertujuan untuk mengidentifikasi faktor penghambat dan pendorong kelembagaan dan menganalisis strategi penguatan kelembagaan sehingga dapat meningkatkan usahatani Jeruk Pamelo

\section{METODE PENELITIAN}

\section{Lokasi dan Waktu Penelitian}

Penelitian ini dilaksanakan di, Kecamatan Sukomoro dan Bendo, serta Takeran Kabupaten Magetan. Pemilihan lokasi dilakukan secara segaja (purposive) dengan pertimbangan bahwa ketiga lokasi merupakan sentra produksi Jeruk Pamelo Kabupaten Magetan Pengumpulan data dilaksanakan pada bulan Maret sampai Agustus 2020.

\section{Jenis dan Sumber Data}

Data yang digunakan dalam penelitian ini adalah data primer dan data sekunder. Data primer diperoleh dari wawancara atau diskusi langsung dengan bantuan kuesioner kepada petani, pengurus kelompok tani dan informan kunci. Data sekunder diperoleh dari berbagai literatur yang bersumber dari lembaga terkait, penelitian terdahulu, buku, jurnal ilmiah, dan sumber data lain yang relevan.

\section{Metode Pengambilan Sampel}

Pada penelitian ini sampel petani berjumlah 37 orang yang diambil secara acak sedrhana (simple random sampling) dan pengambilan purposive untuk pengurus kelembagaan yang terdiri atas ketua, sekertaris, dan bendahara. Pengurus yang diwawancarai berjumlah 21 orang. Selain itu dilakukan depth interview kepada para ahli dan stakeholders melalui Focus Group Discussion (FGD)..

\section{Metode Pengolahan dan Analisis Data}

Data dianalisis menggunakan analisisis deskriptif eksplanatori. Untuk melihat factor pendorong dan penghambat digunakan skala Likert 1 5. Untuk menentukan strategi penguatan kelembagaan pengembangan usahatani jeruk pamelo berdasarkan faktor-faktor pendorong dan faktor penghambat, digunakan analisis FFA (Force Field Analysis) atau analisis medan kekuatan (Sianipar dan Entang 2003)

Langkah-langkah analisis FFA sebagai berikut:
1. Mengidentifikasi factor pendorong dan factor penghambat
2. Identifikasi faktor pendorong dan penghambat yang akan dinilai terdiri atas berbagai aspek sesuai dengan isu strategis, yaitu:

3. Menentukan BObot Faktor (BF)

$$
\mathrm{BF}=\frac{N U}{T N U} \times 100 \%
$$

4. Menentukan Nilai Dukungan dan Nilai Bobot Dukung.

$\mathrm{NBD}=\mathrm{ND} \times \mathrm{BF}$

5. Menentukan Nilai Keterkaitan, Total Nilai Keterkaitan, Nilai Rata-rata Keterkaitan, dan Nilai Bobot Keterkaitan
$\mathrm{NRK}=\frac{T N K}{\Sigma N-1}$
$\mathrm{NBK}=\mathrm{NRK} \times \mathrm{BF}$
6. Menentukan Total Nilai Bobot Faktor
$\mathrm{TNB}=\mathrm{NBD}+\mathrm{NBK}$

7. Penentuan Faktor Kunci Keberhasilan (FKK) dan Diagram Medan Kekuatan Penentuan FKK dilakukan untuk memberikan rating besarnya pengaruh setiap faktor dalam mencapai 
tujuan penelitian, rating setiap FKK ditentukan dengan cara sebagai berkut:

a. FKK dipilih berdasarkan TNB terbesar

b. Apabila TNB sama pilih BF terbesar

c. Apabila BF sama pilih NBD terbesar

d. Apabila NBD sama maka pilih NBK terbesar

e. Apabika NBK sama pilih bedasarkan pengalaman dan pertimbangan rasionalitas.

7. Membuat Diagram Medan Kekuatan

Diagram medan kekuatan merupakan gambaran ilustrasi tarik menarik antara faktor pendorong dan faktor penghambat dalam memperkuat kelembagaan usahatani Jeruk Pamleo di Kabupaten Magetan,

\section{HASIL DAN PEMBAHASAN}

\section{Karakteristik Petani Sampel}

Hasil analisis menunjukkan bahwa petani pengelola usahatani pamelo didominasi oleh lakilaki $(81 \%)$ dan wanita $(19 \%)$. Umur rata rata petani di Kecamatan terpilih adalah 57 tahun. Angka ini menunjukkann bahwa petani pamelo didominasi oleh kelompok petani tua. Hal ini menunjukkan petani sampel barada pada umur yang cukup matang dalam melakukan usahatani pamelo. Sebagian besar petani berumur antara $56-65$ tahun $(37,84 \%)$, dan hampir $27 \%$ petani pamelo di ketiga kecamatan berumur lebih dari 66 tahun.

Demikian halnya dilihat dari sisi pendidikan , para petani sebagian besar berpendidikan SD (49\%), dan hanya 3 persen petani berpendidikan sarjana. Pengalaman berusahatani jeruk pamelo bervariasi. Sebagian besar petani mempunyai pengalaman antara 11-20 tahun (35\%), 21-30 tahun (29\%) dan hanya sedikit (8\%) mempunyai pengalaman di atas 41 tahun. Berdasarkan sifat pekerjaan, sebagian besar responden $(88 \%)$ menyatakan usahatani pamelo merupakan usaha utama dan 22 persen hanya sebagai usaha sampingan. Jumlah tanggungan keluarga sebagian besar (65\%) berjumlah antara 1-3 orang. Sebagian besar petani sampel menyatakan mereka rata- rata mempunyai 2 orang anak, jumlah tanggungan keluarga yang lebih dari empat dikarenakan adanya anggota keluarga lain yang tinggal serumah, dan tidak mempunyai pendapatanJumlah tanggungan keluarga sebagian besar (65\%) berjumlah antara 1-3 orang. Sebagian besar petani sampel menyatakan mereka rata- rata mempunyai 2 orang anak, jumlah tanggungan keluarga yang lebih dari empat dikarenakan adanya anggota keluarga lain yang tinggal serumah, dan tidak mempunyai pendapatan

\section{Karakteristik Pengurus Kelompok Tani}

Berdsarkan hasil penelitian diketahui bahwa umur rata-rata pengurus kelompok tani adalah 54 tahun. Persentase jumlah pengurus berdasarkan umur, (57\%) pengurus gapoktan berumur di antara 51 sampai 60 tahun, hal ini menggambarkan bahwa petani yang menjadi pengurus gapoktan merupakan kelompok petani tua.Berdasakan jenis kelamin, $90 \%$ pengurus poktan laki-laki dan sisanya $(10 \%)$ berjenis kelamin perempuan. Hal ini menunjukkan bahwa pengurus masih didominasi oleh kaum laki-laki. Berdasarkan tingkat pendidikan formal terakhir yang diselesaikannya, dari sebagian besar (62\%) pengurus gapoktan menyelesaikan pendidikan di tingkat Sekolah Menengah Atas (SMA dan hanya $5 \%$ berpendidikan SD. 
Kelembagaan agribisnis Pamelo di Kabupaten Magetan terdiri atas:

1. Dinas Pertanian selaku pihak dari pemerintah daerah yang bertindak sebagai pembina dengan memberikan bantuan material maupun non material kepada kelembagaan pelaku agribisnis (kelembagaan pengadaan saprodi, budidaya, pengolahan hasil produksi dan pemasaran). Bantuan non material berwujud penyuluhan, maupun pendampingan kelembagaan agribisnis dalam menjalankan kebijakan yang dibuat oleh pemerintah, baik itu pemerintah propinsi Jawa Timur maupun pemerintah Kabupaten Magetan.

2. Asosiasi Pamelo Magetan (APM) yang diharapkan dapat bertindak bertindak sebagai pendukung kelembagaan pelaksana agribisnis dengan menjadi perantara petani pamelo selaku anggota dengan kelembagaan agribisnis yang lain maupun dengan Dinas Pertanian guna memperlancar kegiatan agribisnis jeruk pamelo.

3. Kelembagaan pengadaan saprodi

4. Kelembagaan budidaya

5. Kelembagaan pengolahan hasil produksi

6. Kelembagaan pemasaran

\section{Analisis Faktor Penghambat dan Pendorong Usahatani Jeruk Pamelo di Kabupaten Magetan Faktor Penghambat}

Berdasarkan hasil penelitan ditemukan bahwa urutan faktor penghambat dalam usahatani Jeruk Pamelo yaitu berdasarkan nilai TNB terbesar dan urutan Faktor Kunci Keberhasilan(FKK) diperoleh hasil :

1. Kurangnya akses informasi dengan TNB sebesar 0,38
2. Tingginya serangan hama dan penyakit dengan TNB sebesar 0,37

3. Lemahnya manajemen gapoktan dengan TNB sebesar 0,36

4. kemarau panjang dengan TNB sebesar 0,34

5. Lemahnya peran serta petani dalam kelompok dengan TNB sebesar 0,34

6. Harga ditentukan tengkulak dengan TNB sebesar 0,33

7. Rendahnya kerjasama dalam pengadaan saprodi dengan TNB sebesar 0,33

8. Lemahnya akses pasar dengan TNB sebesar 0,32

9. Pemeliharaan pamelo relatif terbatas dengan TNB sebesar 0,32

10. Sebagian besar penjualan kepada tengkulak dengan TNB sebesar 0,31

11. Kualitas bibit belum optimal dengan TNB sebesar 0,31

12. Penerapan teknologi budidaya terbatas dengan TNB sebesar 0,30

13. Umur petani tua dengan TNB sebesar 0,29

14. Masih menggunakan sistem tebasan dengan TNB sebesar 0,29

15. Harga tidak ditentukan oleh kualitas buah dengan TNB sebesar 0,25

16. Kurangnya akses ke lembaga keuangan dengan TNB sebesar 0,24

17. Pendidikan petani relatif terbatas dengan TNB sebesar 23

18. Pandemic dengan TNB 0,22

Hasil ini menjelaskan bahwa dari 18 faktor penghambat akan memberikan pengaruh yang berbedabeda terhadap pengembangan usahatani pamelo. Nilai FKK 1 sampai 6 merupakan faktor penghambat yang memberikan pengaruh sangat besar, nilai FKK 7 sampai 12 merupakan faktor penghambat yang cukup berpengaruh dan nilai FKK 13 sampai 
18 merupakan faktor penghambat yang kadang-kadang berpengaruh.

Berdasarkan hasil perhitungan Total Nilai Bobot (TNB) faktor penghambat sebesar 5,55 dengan TNB kelemahan 4,62 dan ancaman 0,94 (Lampiran 1). Hal ini menjelaskan bahwa nilai kelemahan

lebih besar dari pada nilai ancamannya, sehingga gapoktan dapat meminimalisir kelemahan dan mengatasi ancaman yang terjadi.

\section{Faktor Pendorong}

Berdasarkan hasil identifikasi factor pendorong diperoleh urutan sebagai berikut:

1. keberagaman aksesi dengan TNB sebesar 0,89

2. petani relatif berpengalaman dengan TNB sebesar 0,87

3. kemudahan menjual hasil kepada tengkulak dengan TNB sebesar 0,86

4. aktifnya komunikasi petani dengan TNB sebesar 0,83

5. program bantuan bibit dengan TNB sebesar 0,83

6. petani aktif mencari informasi budidaya dengan TNB sebesar 0,83

7. program bimbingan dan penyuluhan dengan TNB sebesar 0,79

8. lahan milik sendiri dengan TNB sebesar 0,77

9. kesesuaian materi PPL dengan TNB sebesar 0,69

10. Adanya pedoman teknik budidaya dengan TNB sebesar 0,57

11. adanya kios sarana produksi dengan TNB sebesar 0,50

12. Adanya APM dengan TNB sebesar 0,48

Berdasarkan hasil perhitungan analisis FFA diketahui bahwa TNB faktor pendorong adalah 8,91, terdiri atas TNB kekuatan 5,05 dan peluang 3,85 (Lampiran 2). Hal ini menjelaskan bahwa usahatani Jeruk Pamelo di Kabupaten Magetan memiliki kekuatan yang cukup untuk memanfatkan peluang.

\section{Strategi Pengembangan}

Berdasarkan analisi FFA

diketahui bahwa TNB faktor pendorong lebih besar dari TNB faktor penghambat, hal ini menjelaskan bahwa gapoktan memiliki potensi untuk mengembangkan usahatani Jeruk Pamelo.

Strategi yang $\begin{array}{r}\text { dapat } \\ \text { adalah: }\end{array}$
direkomendasikan meningkatkan akses informasi dan kerjasama dengan berbagai lembaga penunjang seperti Dinas Pertanian Kabupaten Magetan, Asosiasi Pamelo Magettan (APM), membuat jadwal rutin penyampaian informasi, bimbingan dan evaluasi terkait pengembangan usahatani Jeruk Pamelo, serta terus meningkatkan keberagaman aksesi, bekerjasama dengan lembaga lain (terutama lembaga pmasaran atau asosiasi yang dapat meningkatkan bergaining position petani, akses dan informasi pemasaran.

$\begin{array}{rlr} & \text { Peningkatan akses informasi } \\ \text { dengan lembaga } & \text { terkait penting }\end{array}$ dilakukan untuk mengembangkan usahatani Jeruk Pamelo dan mengatasi beragai hambatannya. Penigkatan akses informasi ini juga dapat meningkatkan pengetahuan petani dan para pengurus untuk memperoleh wawasan yang lebih luas dan teraktual. Cara yang dapat ditempuh untuk peningkatan akses ini bisa melalui kegiatan rapat rutim (salapanan).

\section{KESIMPULAN}

Hasil penelitian menunjukkan terdapat 18 faktor penghambat yang 
terdiri atas kelemahan dan ancaman. Berdasarkan hasil TNB, factor penghambat yang berpengaruh kuat terhadap usahatani pamelo adalah kurangnya akses informasi, tingginya serangan hama dan penyakit, lemahnya manajemen gapoktan, kemarau panjang Lemahnya peran serta petani dalam kelompok, dan harga ditentukan tengkulak...

Terdapat 12 faktor pendorong penguatan kelembagaan. Faktor pendorong yang berpengaruh kuat terhadap usahatani pamelo adalah keberagaman aksesi,

petani relatif berpengalaman kemudahan menjual hasil kepada tengkulak dan aktifnya komunikasi petani dengan

Berdsarkan hasil FKK factor TNB kelemahan lebih besar dari pada nilai ancamannya, sehingga petani dapat meminimalisir kelemahan dan mengatasi ancaman yang terjadi TNB kekuatan lebih besar dari TNB peluang. Hal ini menjelaskan bahwa usahatani Jeruk Pamelo di Kabupaten Magetan memiliki kekuatan yang cukup untuk memanfatkan peluang.Strategi yang dapat direkomendasikan untuk memperkuat pengembangan usahatani Jeruk pamelo adalah meningkatkan akses informasi, kerjasama, mengembangkan keberagaman aksesi Jeruk Pamelo dan membentuk tim pemasaran.

Saran

Untuk mengembangkann jeruk pamelo di diperlukan akses informasi dan kerjasama dengan berbagai lembaga penunjang seperti Dinas Pertanian Kabupaten Magetan, Asosiasi Pamelo Magettan (APM), yang dapat meningkatkan bergaining position petani.

\section{DAFTAR PUSTAKA}

Anantanyu, Sapja. 2011. Kelembagaan Petani: Peran dan Strategi Pengembangan Kapasitasnya SEPA:Vol.7 No.2 Pebruari 2011 : 102 - 109. ISSN: 18299946102

BPS. 2019. Laporan Perekonomian Indonesia 2019. Jakarta: BPS Indonesia

FAO. $2018 . \quad$ FAOSTAT. http://www.fao.org/faostat/en/\#r enkings/countries by commodity [05 Maret 2020]

Kementan. 2016. Outlook Jeruk 2016. Jakarta: Pusat Data dan Sistem Informasi Pertanian

Peraturan Menteri Pertanian Nomor: 82/ tani dan Gabungan Kelompok

Permentan/Ot.140/8/2013

Tentang Pedoman Pembinaan Kelompok tani. Kementerian Pertanian.

Peraturan Menteri Pertanian Nomor :48/Permentan/OT.140/2009

Kementrian Pertanian. 2016.

Sumardjo. 2012. Rekayasa Sosial. Dalam Poerwanto, Roedhy et.al.(2012). Merevolusi Revolusi Hijau (Pemikiran Guru Besar IPB Buku III) Sumardjo. 2012. Rekayasa Sosial. Dalam Poerwanto, Roedhy et.al.(2012). Merevolusi Revolusi Hijau (Pemikiran Guru Besar IPB Buku III)

Suswadi dan Sutarno. 2017. Analisa Dinamika dan Kemandirian Kelembagaan Ekonomi Petani dengan Penerapan Pertanian Organik Bersertifikasi di Kabupaten Boyolali. Prosiding seminar Nasional Progam Studi Bimbingan Konseling, 22 Agustus 2017.

Sianipar dan Entang. 2003. Teknikteknik Analisis Manajemen. 
Jakarta : Lembaga Administrasi 5617-01-0 Ekonomi dan Bisnis Negara RI

(SNAPER-EBIS 2017

Yuniarti, Sri; Djoko Susilo, Fuad

Albayumi. 2017. Penguatan

Kelembagaan dalam Upaya

Meningkatkan Kesejahteraan

Petani Tebu. Prosiding Seminar nasional dan Call for Paper) Jember. 27-28 Oktober 2017 (hal 498-505) ISBN:978-602- 
Lampiran 1

\begin{tabular}{|c|c|c|c|c|c|c|c|c|c|}
\hline & Faktor penghambat & $\mathrm{NF}$ & $\mathrm{BF}$ & ND & NBD & NRK & NBK & TNB & FKK \\
\hline H1 & umur petani tua & 3.89 & 0.05 & 2.46 & 0.13 & 3.00 & 0.16 & 0.29 & 13 \\
\hline $\mathrm{H} 2$ & pendidikan relatif terbatas & 3.21 & 0.04 & 2.11 & 0.09 & 3.08 & 0.14 & 0.23 & 17 \\
\hline $\mathrm{H} 3$ & penerapan teknologi budidaya terbatas & 3.73 & 0.05 & 2.14 & 0.11 & 3.74 & 0.19 & 0.30 & 12 \\
\hline $\mathrm{H} 4$ & kualitas bibit belum optimal & 3.87 & 0.05 & 2.43 & 0.13 & 3.34 & 0.18 & 0.31 & 11 \\
\hline H5 & pemeliharaan pamelo relatif terbatas & 3.97 & 0.05 & 2.19 & 0.12 & 3.61 & 0.20 & 0.32 & 9 \\
\hline H6 & masih menggunakan sistem tebasan & 3.89 & 0.05 & 2.13 & 0.11 & 3.23 & 0.17 & 0.29 & 14 \\
\hline $\mathrm{H} 7$ & harga ditentukan tengkulak & 4.61 & 0.06 & 1.76 & 0.11 & 3.48 & 0.22 & 0.33 & 6 \\
\hline $\mathrm{H} 8$ & sebagian besar penjualan kepada tengkulak & 4.65 & 0.06 & 1.42 & 0.09 & 3.44 & 0.22 & 0.31 & 10 \\
\hline H9 & lemahnya akses pasar & 4.05 & 0.06 & 2.28 & 0.13 & 3.52 & 0.20 & 0.32 & 8 \\
\hline H10 & harga tidak ditentukan oleh kualitas buah & 3.64 & 0.05 & 1.49 & 0.07 & 3.51 & 0.18 & 0.25 & 15 \\
\hline H11 & rendahnya kerjasama dalam pengadaan saprodi & 4.13 & 0.06 & 2.44 & 0.14 & 3.33 & 0.19 & 0.33 & 7 \\
\hline H12 & kurangnya akses kelembaga keuangan & 3.14 & 0.04 & 2.34 & 0.10 & 3.13 & 0.14 & 0.24 & 16 \\
\hline H13 & kurangnya akses informasi & 4.17 & 0.06 & 2.42 & 0.14 & 4.23 & 0.24 & 0.38 & 1 \\
\hline H14 & lemahnya manajemen gapoktan & 4.09 & 0.06 & 2.24 & 0.13 & 4.11 & 0.23 & 0.36 & 3 \\
\hline \multirow[t]{3}{*}{$\mathrm{H} 15$} & lemahnya peran serta petani dalam kelompok & 4.14 & 0.06 & 2.43 & 0.14 & 3.56 & 0.20 & 0.34 & 5 \\
\hline & & & 0.82 & 32.28 & 1.75 & 52.31 & 2.86 & 4.62 & \\
\hline & $\mathrm{T}$ & & & & & & & & \\
\hline H16 & kemarau panjang & 4.89 & 0.07 & 1.86 & 0.13 & 3.24 & 0.22 & 0.34 & 4 \\
\hline H17 & tingginya serangan hama dan penyakit & 4.89 & 0.07 & 1.83 & 0.12 & 3.68 & 0.25 & 0.37 & 2 \\
\hline \multirow[t]{3}{*}{$\mathrm{H} 18$} & Pandemic & 3.41 & 0.05 & 2.27 & 0.11 & 2.37 & 0.11 & 0.22 & 18 \\
\hline & & & 0.18 & 5.96 & 0.36 & 9.29 & 0.58 & 0.94 & \\
\hline & Total Faktor Penghambat & 72.37 & 1.00 & 38.24 & 2.11 & 61.60 & 3.44 & 5.55 & \\
\hline
\end{tabular}


Lampiran 2

\begin{tabular}{|c|c|c|c|c|c|c|c|c|c|}
\hline No & Faktor pendorong & NF & $\mathrm{BF}$ & ND & NBD & NRK & NBK & TNB & FKK \\
\hline & $\mathrm{S}$ & & & & & & & & \\
\hline D1 & Petani relatif berpengalaman & 4.67 & 0.10 & 4.86 & 0.47 & 4.08 & 0.40 & 0.87 & 2 \\
\hline D2 & Keberagaman aksesi & 4.89 & 0.10 & 4.79 & 0.49 & 3.95 & 0.40 & 0.89 & 1 \\
\hline D3 & Lahan milik sendiri & 4.56 & 0.10 & 4.65 & 0.44 & 3.44 & 0.33 & 0.77 & 8 \\
\hline D4 & Kemudahan menjual hasil kepada tengkulak & 4.56 & 0.10 & 4.85 & 0.46 & 4.19 & 0.40 & 0.86 & 3 \\
\hline D5 & $\begin{array}{l}\text { Petani aktif mencari informasi teknologi } \\
\text { budidaya }\end{array}$ & 4.47 & 0.09 & 4.64 & 0.43 & 4.20 & 0.39 & 0.83 & 6 \\
\hline D6 & Aktifnya komunikasi petani & 4.48 & 0.09 & 4.57 & 0.43 & 4.28 & 0.40 & 0.83 & 4 \\
\hline & $\begin{array}{l}\text { Total S } \\
\mathrm{O}\end{array}$ & 27.63 & 0.58 & 28.36 & 2.73 & 24.14 & 2.32 & 5.05 & \\
\hline D7 & Adanya pedoman teknik budidaya & 3.87 & 0.08 & 3.11 & 0.25 & 3.9 & 0.32 & 0.57 & 10 \\
\hline D8 & Program bantuan bibit & 4.64 & 0.10 & 4.57 & 0.44 & 3.95 & 0.38 & 0.83 & 5 \\
\hline D9 & Program bimbingan dan penyuluhan & 4.32 & 0.09 & 4.35 & 0.39 & 4.36 & 0.39 & 0.79 & 7 \\
\hline D10 & Adanya APM & 3.65 & 0.08 & 2.87 & 0.22 & 3.45 & 0.26 & 0.48 & 12 \\
\hline D11 & Adanya kios sarana produksi & 3.72 & 0.08 & 3.14 & 0.24 & 3.3 & 0.26 & 0.50 & 11 \\
\hline D12 & Kesesuaian materi PPL & 4.41 & 0.09 & 3.42 & 0.32 & 4.05 & 0.37 & 0.69 & 9 \\
\hline & Total O & & 0.51 & 21.46 & 1.87 & 23.01 & 1.99 & 3.85 & \\
\hline & Total Faktor pendorong & 47.83 & 1.00 & 46.40 & 4.28 & 43.10 & 3.94 & 8.91 & \\
\hline
\end{tabular}

